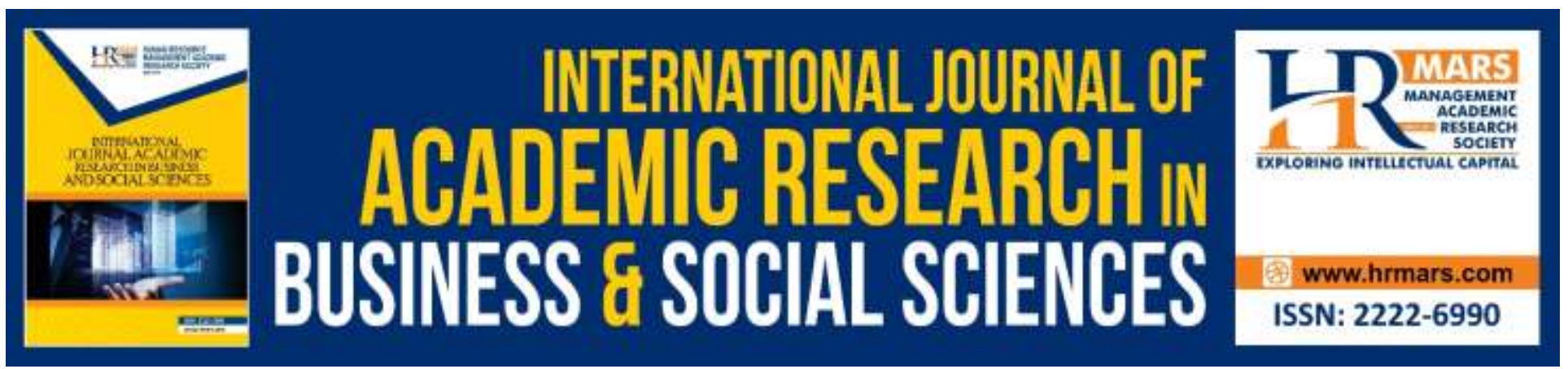

\title{
The Effects of ASEAN Economic Community (AEC) Blueprint Adoption on Intra-ASEAN Trade on Manufacturing Products
}

Colin Wong Koh King, Venus Khim-Sen Liew, Mohammad Affendy Arip

To Link this Article: http://dx.doi.org/10.6007/IJARBSS/v10-i2/6957

DOI:10.6007/IJARBSS/v10-i2/6957

Received: 24 January 2020, Revised: 03 February 2020, Accepted: 12 February 2020

Published Online: 29 February 2020

In-Text Citation: (King et al., 2020)

To Cite this Article: King, C. W. K., Liew, V. K.-S., \& Arip, M. A. (2020). The Effects of ASEAN Economic Community (AEC) Blueprint Adoption on Intra-ASEAN Trade on Manufacturing Products. International Journal of Academic Research in Business and Social Sciences, 10(2), 680-690.

Copyright: (C) 2020 The Author(s)

Published by Human Resource Management Academic Research Society (www.hrmars.com)

This article is published under the Creative Commons Attribution (CC BY 4.0) license. Anyone may reproduce, distribute, translate and create derivative works of this article (for both commercial and non-commercial purposes), subject to full attribution to the original publication and authors. The full terms of this license may be seen

at: http://creativecommons.org/licences/by/4.0/legalcode

Vol. 10, No. 2, 2020, Pg. 680 - 690

http://hrmars.com/index.php/pages/detail/IJARBSS

JOURNAL HOMEPAGE

Full Terms \& Conditions of access and use can be found at http://hrmars.com/index.php/pages/detail/publication-ethics 


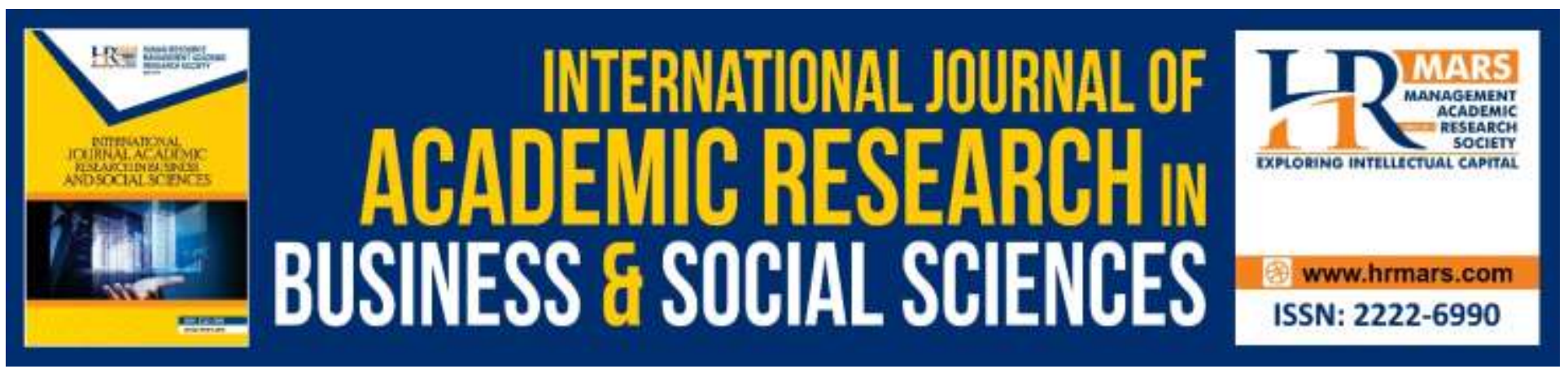

\title{
The Effects of ASEAN Economic Community (AEC) Blueprint Adoption on Intra-ASEAN Trade on Manufacturing Products
}

\author{
Colin Wong Koh King, Venus Khim-Sen Liew, Mohammad Affendy \\ Arip \\ Department of Economics, Faculty of Economics and Business, Universiti Malaysia Sarawak \\ Email: ksliew@unimas.my
}

\begin{abstract}
This paper seeks to explore the effects of ASEAN Economic Community (AEC) Blueprint adoption since 20 November 2007 on the bilateral manufacturing trade between the ASEAN member countries and their trading partners. Ten ASEAN member countries and their 39 trading partners are considered in this study. The gravity model is estimated on a set of panel data over the sample period of 1995 to 2014. Overall, it is found that AEC has created substantial trade creation effects for the exports of tobacco \& manufactured tobacco substitutes, and limestone materials for manufacture of lime. On the other hand, there are substantial trade diversion effects for the exports of the fur-skins \& artificial fur manufactures, manufactures of plaiting material \& basketwork, miscellaneous manufactured articles, as well as the machines $\&$ apparatus.
\end{abstract}

\section{Introduction}

On 20 November, 2007, ASEAN Economic Community (AEC) blueprint was adopted with the aim to create a single market across ASEAN nations. Generally, AEC is meant to be a single market and production base with the free movement of products, services, investments, trained workforce and freer flow of capital, which will make the association to be more dynamic and competitive with recent approaches and measures in strengthening the achievement of its existing economic schemes; progressing the regional integration in the priority segments; simplifying the movements of trained workforce, business groups and endowments; and pointing out the standard procedures of ASEAN countries. Ultimately, $A E C$ is meant to sustain the balanced economic growth within the region as well as to reduce poverty and socio-economic dissimilarities by 2020 . 
The ASEAN leaders had agreed to accelerate the adjustment for eight priority goods sectors ${ }^{1}$ together with four service segments ${ }^{2}$ in their Summit during 2003 as one of the significant portions to accomplish the identified objective. Generally, each of these priority sectors holds a roadmap that brings together the specific measures of the segment with all-inclusive outlines which are the additions to the whole of its primary segments, such as the trade facilitation measures. Through acquiring the capability of these major segments, this might facilitate ASEAN to be more dependent without the value-added financial measure together with the employment within the region.

In addition, the ASEAN leaders had adopted the ASEAN Economic Community Blueprint at the 13th ASEAN Summit, on 20 November 2007 in Singapore, to serve as a comprehensible master plan that drives the formation of the ASEAN Economic Community in $2020^{3}$. Generally, the AEC foresees the following key elements: (a) a single market and production base, (b) a highly competitive economic region, (c) a region of unbiased economic development, and (d) a region effusively integrated into the international economy.

The AEC agreement not only focuses on the tariff reductions on substantial product groups; however, it also focuses on the elimination of non-tariff barriers, quantitative margins as well as some other cross-border measures. In consequence of eliminating the tariff barriers between the ASEAN member countries, AEC would further develop the ASEAN economies into a single market and production base.

The prior study on AEC by Soesastro (2005) had shown the growth towards the development of the community by examining the trade trends within the ASEAN countries. Nevertheless, the important roles of the selected priority sectors in stimulating the ASEAN trade should also be observed. Secondly, Soesastro (2005) discussed the key model of AEC. It observed the major fundamentals of a broader and deeper economic integration method for ASEAN, which comprised the ultimate form of integration, and the appropriate method to achieve it in combination with the obligation for institutional growth to implement it. On the other hand, this study aims to observe the impact of AEC on bilateral aggregate and manufacturing trade between ASEAN member countries.

\section{Literature Review}

Oh and Sardar (2013) found that its trade patterns are consistent with the gravity model estimation. They also found that the exports of Bangladesh are significantly reliant on the US market, by comparing the predicted and actual trade volumes of Bangladesh. In addition, Rasoulinezhad and Kang (2016) concluded that the gravity equation fits well on the data and thus established the presence of long-term relationships between bilateral trade flows and primary components ${ }^{4}$ of gravity model. They found that the trade flows of South Korea- Organization of the Petroleum Exporting Countries (OPEC) are well explained by the factors that impacted the energy security of South Korea such as the oil reserves, transportation costs as well as the political stability.

By investigating the major determining factors of bilateral trade flows on MERCOSUR countries, García et al. (2013) concluded that the impact of trade agreement holds modest positive impact on

\footnotetext{
${ }^{1}$ Agro-based products, fisheries, healthcare products, rubber-based products, wood-based products, textiles and garments, electronics and information and communication technology (ICT), and automotive.

${ }^{2}$ e-ASEAN, healthcare, air travel and tourism

${ }^{3}$ The implementation date was brought forward from original 2020 to 31 December 2015.

${ }^{4} \mathrm{GDP}$, income (GDP per capita), the difference in income, exchange rate, the openness level, distance and WTO membership.
} 
the trade flows of MERCOSUR countries, namely Brazil, Argentina, Paraguay, and Uruguay. Likewise, Panda and Sethi (2015) found that the trade flows of India hold positive effects on the economic sizes of its trading partners and the dummy variable of common colonizer while it negatively affected by the distance between two countries. They also found that per capita income holds significant effects on trade flows for the pre-crisis period but bereaved its importance throughout the post-crisis period. At the same time, Sultan and Munir (2015) found that the determinants of export and import flows are different from the determinants of total trade. They also found that Pakistan hold highest trade potential with Norway and Hungry; the highest export potentials found in the case of Switzerland and Hungry while the highest import potentials found in the case of Norway, Philippines, Portugal and Greece.

Tumwebaze and Nahamya (2015) concluded that the export flows of Uganda positively affected by GDPs, GDP per capita of its trading partners, differences in per capita GDP, real exchange rate, official common language, contiguity, as well as the establishment of Common Market for Eastern and Southern Africa (COMESA) and East African Community (EAC) while it negatively affected the Uganda's GDP per capita as well as the geographical distances between Uganda and its trading partners.

Eita (2016) concluded that the export flows positively affected the economic sizes of both exporting \& importing countries and common border variables whereas the GDP per capita and real exchange rates of Namibia do not hold any substantial effects on the export volumes.

\section{Methodology}

In the present study, the gravity model is employed in panel estimation from the period of 1995 to 2014 between ASEAN-10 member countries and its 39 trading partners, primarily the Asia countries and some developed and developing countries. Bilateral exports are presented in dollar terms (constant prices ${ }^{5}$ ) taken from the database of United Nation (2016). The GDP and the population data are acquired from World Bank (2016). Common language, common border, island or landlocked countries and distance measures are taken from Centre D'Etudes Prospectives Et D'Informations Internationales (CEPII, 2016).

This paper intends to attain the unbiased estimations for AEC dummy variable, specifically the trade creation or diversion effects within the trade-bloc $\left(F T A_{-} 1_{i j t}\right)$, trade creation or diversion effects for export or import between intra-bloc $\left(F T A_{-} 2_{i j t}\right)$ and extra-bloc countries $\left(F T A_{-} 3_{i j t}\right)$, by employing a panel data method that controls for the unobserved heterogeneity based on the country-and-time effects as well as the time-invariant country-pair effects.

The basic gravity equation explains the volume of bilateral exports from country $i$ to country $j$. In the basic form of gravity equation, the bilateral exports from country $i$ to country $j$ are determined by their economic sizes (GDP), populations, geographical distances variables such as distance, border, landlocked and island countries. Therefore, this study initially estimates the following model:

$$
\begin{aligned}
& \ln X_{i j t}=\beta_{0}+\beta_{1} \ln Y_{i t}+\beta_{2} \ln Y_{j t}+\beta_{3} \ln \text { Pop }_{i t}+\beta_{4} \ln \text { Pop }_{j t}+\beta_{5} \ln \text { Dist }_{i j}+\beta_{6} \text { Lang }_{i j}+\beta_{7} \text { border }_{i j}+\beta_{8} \text { llocked }_{i t}+ \\
& \beta_{9} \text { llocked }_{j \mathrm{t}}+\beta_{10} \text { island }_{\mathrm{it}}+\beta_{11} \text { island }_{\mathrm{jt}}+\varepsilon_{\mathrm{ij}}
\end{aligned}
$$

where,

$X_{i j t}=$ Total trade at time period t;

\footnotetext{
${ }^{5}$ The constant prices reflected as Export/US GDP Deflator.
} 
INTERNATIONAL JOURNAL OF ACADEMIC RESEARCH IN BUSINESS AND SOCIAL SCIENCES Vol. 10, No. 2, Feb, 2020, E-ISSN: 2222-6990 @ 2020 HRMARS

$Y_{i t}$ and $Y_{j t}=$ GDP of the exporting and importing country at time period t;

$\mathrm{Pop}_{i t}$ and $\mathrm{Pop}_{j t}=$ Populations of the exporting and importing country at time period t;

Dist $_{i j}=$ Distance between two countries;

Lang $_{i j}=$ Dummy variable which takes the value of 1 if the two countries share the common language and zero if otherwise;

$\operatorname{border}_{i j}=$ Dummy variable which takes the value of 1 if the two countries share the common border and zero if otherwise;

llocked $_{i}$ and llocked $_{j}=$ Dummy variable which takes the value of 1 if country i or $\mathrm{j}$ is landlocked (no sea ports or direct sea access) and zero if otherwise;

island $_{i}$ and island $_{j}=$ Dummy variable which takes the value of 1 if country $i$ or $j$ is an island country and zero if otherwise; and

$\varepsilon_{i j}=$ error terms.

This study estimates Equation 1 by applying a pooled OLS estimation method and excludes the time and individual country dummy variables from the model. Although the coefficients of pooled OLS can be biased and variable in consequence of ignoring multilateral resistance terms and heterogeneity on time and country-specific effects, this study still proceeds with the estimations by applying this basic model as the benchmark for other specifications.

The dummy variables of AEC will be further added to establish the effect of AEC implementation on intra-regional trade between ASEAN countries. Therefore, the augmented gravity equations are presented as:

$$
\begin{aligned}
& \ln X_{i j t}=\beta_{0}+\beta_{1} \ln Y_{i t}+\beta_{2} \ln Y_{j t}+\beta_{3} \ln \text { Pop }_{i t}+\beta_{4} \ln \text { Pop }_{j t}+\beta_{5} \ln D i s t_{i j}+\beta_{6} \text { Lang }_{i j}+\beta_{7} \text { border }_{i j}+\beta_{8} \text { llocked }_{i t}+ \\
& \beta_{9} \text { llocked }_{i \mathrm{t}}+\beta_{10} \text { island }_{\mathrm{it}}+\beta_{11} \text { island }_{\mathrm{jt}}+\varphi_{1} \mathrm{AEC}{ }_{-} 1_{\mathrm{ijt}}+\varphi_{2} \mathrm{AEC}{ }_{-}{ }_{\mathrm{ijt}}+\varphi_{3} A E \mathrm{~A}_{-} 3_{\mathrm{ijt}}+\varepsilon_{\mathrm{ij}}
\end{aligned}
$$

Equation 2 describes an augmented gravity equation that includes the AEC dummy variables. Basically, AEC_1 takes the value of 1 when countries $i$ and $j$ are members of AEC in year $t$, zero otherwise. AEC_2 is a dummy variable that takes the value of 1 when country $i$ is a member of the $A E C$ and $j$ is not in year $t$, zero otherwise. AEC_3 takes the value of 1 when country $i$ is non-AEC member and $j$ is a member in year $t$, zero otherwise. Generally, a positive coefficient implies that trade creation effects between the ASEAN member countries at the same time as the negative coefficients indicate trade diversion effects (DeRosa, 2007).

This study employs the fixed effects model for estimations ${ }^{6}$. Furthermore; the second specification includes a model with the dyadic fixed effects estimation. The time fixed effects are also included to control for the macroeconomic effects, such as global economic developments and recessions. Note that the process of demean in the FE model comes without regard for estimating the effect of the bilateral time-invariant determinants, such as distance, common border or some other economic, political as well as the cultural factors. Hence, Dist $_{i j}$, Lang $_{i j}$, border $_{i j}$, llocked $_{i}$, llocked $_{j}$, island $i$ and $i_{\text {sland }}$ will be omitted from the estimations as the variables are fixed over time.

Accordingly, the model presented as:

$\ln X_{i j t}=\beta_{0}+\beta_{1} \ln Y_{i t}+\beta_{2} \ln Y_{j t}+\beta_{3} \ln \operatorname{Pop}_{i t}+\beta_{4} \ln \operatorname{Pop}_{j \mathrm{tt}}+\phi_{1} A E C_{-} 1_{i j t}+\phi_{2} A E C \_2_{i j t}+\varphi_{3} A E C \_3_{i j t}+\delta_{t}+\pi_{i j}+\mu_{i j t}(3)$

${ }^{6}$ This paper applies Hausman specification test to check whether the unobserved time-invariant heterogeneity is orthogonal to the timevarying of the error term and the null hypothesis was rejected, hence invalidating a random effects specification. 
INTERNATIONAL JOURNAL OF ACADEMIC RESEARCH IN BUSINESS AND SOCIAL SCIENCES Vol. 10, No. 2, Feb, 2020, E-ISSN: 2222-6990 @ 2020 HRMARS

Following the methods recommended by Baier and Bergstrand (2007), the panel data specification allows the study to control for both time-varying multilateral resistance terms as well as to keep away from the endogeneity bias of the gravity equation through introducing the country-and-time effects while retaining the country-pair fixed effects. Generally, the gravity equations are presented as:

$$
\ln X_{i j t}=\beta_{0}+\phi_{1} A E C \_1_{i j t}+\phi_{2} A E C \_2_{i j t}+\varphi_{3} A E C \_3_{i j t}+\pi_{i j}+\epsilon_{i t}+\psi_{j t}+\mu_{i j t}
$$

In the fourth model mentioned above, this study has introduced country-and-time fixed effects and country-pair fixed effects with a view to correct the bias provoked by unobserved time-varying multilateral resistance terms. By doing so, this will minimize the omitted variable bias and "filters" the real effects of the free trade agreement on bilateral trade flows.

\section{Empirical Results}

Six manufacturing products namely, (1) Tobacco \& manufactured tobacco substitutes, (2) Fur-skins \& artificial fur, manufactures thereof, (3) Manufactures of plaiting material, basketwork, etc., (4) Miscellaneous manufactured articles, (5) Limestone materials for manufacture of lime or cement, and 6) Machines \& apparatus are considered in this study. The panel data gravity model based on the country-and-time as well as the country-pair fixed effects are estimated to analysis the effects of AEC agreements on various category of manufacturing products. The results are reported in Table 1.

\section{Panel Data Gravity Estimations}

It is observed from the results, for tobacco and manufactured tobacco substitutes as shown in Column (1), the coefficients of $A E C_{-} 1_{i j t}\left(\theta_{1}=-1.033\right)$ and $A E C_{-} 2_{i j t}\left(\theta_{2}=-0.131\right)$ are negative while the coefficient of $A E C_{-} 3_{i j t}\left(\theta_{3}=1.499\right)$ is positive and significant at $1 \%$ significance level. $\theta_{1}<0$ and $\theta_{2}<0$ means that AEC has generated the diversion as well as contraction of intra-bloc exports of tobacco \& manufactured tobacco substitutes. Besides, $\theta_{1}<0$ and $\theta_{3}>0$ implies expansion of extra-bloc imports.

The results for fur-skins \& artificial fur in Column (2) reported that the coefficients of $A E C_{-} 1_{i j t}\left(\theta_{1}=-0.883\right)$ and $A E C_{-} 2_{i j t}\left(\theta_{2}=-0.418\right)$ are reported as negative and statistically significant at $1 \%$ level while the coefficients of $A E C_{-} 3_{i j t}\left(\theta_{3}=0.253\right)$ is positive but statistically insignificant. $\theta_{1}<0$ indicates that AEC has generated trade diversion effects in terms of exports, while $\theta_{2}<0$ reveals the contraction of the intra-bloc manufacturing exports. Moreover $\theta_{3}>0$ indicates the expansion of the extra-bloc manufacturing imports.

Similar to the previous types of manufactured products, the coefficients of $A E C_{-} 1_{i j t}$, and $A E C_{-} 2_{i j t}$ for manufactures of plaiting material $\&$ basketwork products are reported as negative and statistically significant $\left(\theta_{1}=-1.107\right.$ and $\left.\theta_{2}=-0.3625\right)$. The positive coefficient of $A E C_{-} 3_{i j t}$ implies expansion of extra-bloc imports for manufactures of plaiting material \& basketwork products.

In line with the results for miscellaneous manufactured articles in Column (4), the coefficients of $A E C_{-} 1_{i j t}$, and $A E C_{-} 2_{i j t}$ are all negative and statistically significant. The negative coefficient of $A E C_{-} 1_{i j t}, \theta_{1}=-1.266$ indicates that AEC has created trade diversion effects. The coefficient of $A E C_{-} 2_{i j t}, \theta_{2}=-0.532$, which represents the lateral exports from the member countries of AEC to non-AEC member countries, shows a statistically significant negative coefficient, which further shows the contraction of the intra-bloc manufacturing exports. Meanwhile, the coefficients of $A E C_{-} 3_{i j t}$, 
INTERNATIONAL JOURNAL OF ACADEMIC RESEARCH IN BUSINESS AND SOCIAL SCIENCES Vol. 10, No. 2, Feb, 2020, E-ISSN: 2222-6990 @ 2020 HRMARS

$\theta_{3}=0.884$ is positive and significant, which indicates the expansion of the extra-bloc manufacturing imports for miscellaneous manufactured articles.

The coefficients of $A E C_{-} 1_{i j t}$ and $A E C_{-} 2_{i j t}$ for limestone materials for manufacture of lime or cement category are reported to be negative $\left(\theta_{1}=-0.321, \theta_{2}=-0.094\right)$. In view of that, an overall trade diversion effects due to the $A E C$ implementation in terms of exports and imports for limestone materials for manufacture of lime or cement category are identified for the coefficients of $A E C_{-} 1_{i j t}$ and $A E C \_2_{i j t}$. Meanwhile, the positive coefficient of $A E C_{-} 3_{i j t}$ indicates the expansion of the extrabloc manufacturing imports for limestone materials for manufacture of lime or cement.

Table 1: Panel data gravity estimations by using disaggregated exports with country-and-time and country-pair fixed effects

\begin{tabular}{|c|c|c|c|c|c|c|}
\hline & $\begin{array}{l}(1) \\
\text { Tobacco \& } \\
\text { manufactured } \\
\text { tobacco } \\
\text { substitutes }\end{array}$ & $\begin{array}{l}\text { (2) } \\
\text { Fur-skins \& } \\
\text { artificial fur, } \\
\text { manufactures } \\
\text { thereof }\end{array}$ & $\begin{array}{l}\text { (3) } \\
\text { Manufactures } \\
\text { of plaiting } \\
\text { material, } \\
\text { basketwork, } \\
\text { etc. }\end{array}$ & $\begin{array}{l}\text { (4) } \\
\text { Miscellaneous } \\
\text { manufactured } \\
\text { articles }\end{array}$ & $\begin{array}{l}\text { (5) } \\
\text { Limestone } \\
\text { materials for } \\
\text { manufacture } \\
\text { of lime or } \\
\text { cement }\end{array}$ & $\begin{array}{l}\text { (6) } \\
\text { Machines } \\
\& \\
\text { apparatus }\end{array}$ \\
\hline$A E C_{-} 1_{i j t}\left(\theta_{1}\right)$ & $\begin{array}{l}-1.033^{* * *} \\
(-3.75)\end{array}$ & $\begin{array}{l}-0.883^{* * *} \\
(-4.33)\end{array}$ & $\begin{array}{l}-1.107^{* * *} \\
(-5.90)\end{array}$ & $\begin{array}{l}-1.266 * * * \\
(-4.68)\end{array}$ & $\begin{array}{l}-0.321 * * * \\
(-2.99)\end{array}$ & $\begin{array}{l}-1.285^{* * *} \\
(-7.90)\end{array}$ \\
\hline$A E C \_2_{i j t}\left(\theta_{2}\right)$ & $\begin{array}{l}-0.131 \\
(-0.74)\end{array}$ & $\begin{array}{l}-0.418^{* * *} \\
(-3.20)\end{array}$ & $\begin{array}{l}-0.3625 * * * \\
(-3.02)\end{array}$ & $\begin{array}{l}-0.532 * * * \\
(-3.07)\end{array}$ & $\begin{array}{l}-0.094 \\
(-1.37)\end{array}$ & $\begin{array}{l}-1.386 * * * \\
(-13.29)\end{array}$ \\
\hline$A E C_{-} 3_{i j t}\left(\theta_{3}\right)$ & $\begin{array}{l}1.499 * * * \\
(5.68)\end{array}$ & $\begin{array}{l}0.253 \\
(1.30) \\
\end{array}$ & $\begin{array}{l}1.242^{* * *} \\
(6.93) \\
\end{array}$ & $\begin{array}{l}0.884 * * * \\
(3.42)\end{array}$ & $\begin{array}{l}0.562 * * * \\
(5.49)\end{array}$ & $\begin{array}{l}-1.338 * * * \\
(-8.61)\end{array}$ \\
\hline Constant & $\begin{array}{l}4.393^{* * *} \\
(14.22)\end{array}$ & $\begin{array}{l}1.367^{* * *} \\
(5.99)\end{array}$ & $\begin{array}{l}1.384^{* * *} \\
(6.59)\end{array}$ & $\begin{array}{l}4.190 * * * \\
(13.84)\end{array}$ & $\begin{array}{l}0.201^{*} \\
(1.75)\end{array}$ & $\begin{array}{l}1.674^{* * * *} \\
(9.18)\end{array}$ \\
\hline$N$ & 29640 & 29640 & 29640 & 29640 & 29640 & 29640 \\
\hline$R$-squared & 0.1460 & 0.2982 & 0.1800 & 0.1428 & 0.0444 & 0.2710 \\
\hline Adj $R$-Squared & 0.1441 & 0.2966 & 0.1782 & 0.1409 & 0.0422 & 0.2693 \\
\hline RMSE & 4.4621 & 3.2981 & 3.0332 & 4.3717 & 1.7352 & 2.6318 \\
\hline
\end{tabular}

Note: Robust and clustered standard errors applied in computing the t-values and t-values are reported below each of the coefficient. Estimation applies the estimator of White's heteroskedasticity-consistent covariance matrix. Data sources: Sectoral exports are extracted from UNCTAD database and are presented in thousand US\$. AFTA_1 takes the value of 1 when countries $i$ and $j$ are AFTA members in year $t$, zero otherwise. AFTA_2 takes the value of 1 when country $i$ is a member of the AFTA and $j$ is not in year $t$, zero otherwise. AFTA_3 takes the value of 1 when country $i$ is non-member of AFTA and $j$ is a member in year $t$, zero otherwise. AEC_1 takes the value of 1 when countries $i$ and $j$ are $A E C$ members in year $t$, zero otherwise. AEC_2 takes the value of 1 when country $i$ is a member of AEC and $j$ is not in year $t$, zero otherwise. AEC_3 takes the value of 1 when country $i$ is the non-member of AEC and $j$ is a member in year $t$, zero otherwise. ACFTA_1 takes the value of 1 when countries $i$ and $j$ are the members of ACFTA in year $t$, zero otherwise. ACFTA_2 takes the value of 1 when country $i$ is a member of ACFTA and $j$ is not in year $t$, zero otherwise. ACFTA_3 takes the 
INTERNATIONAL JOURNAL OF ACADEMIC RESEARCH IN BUSINESS AND SOCIAL SCIENCES Vol. 10, No. 2, Feb, 2020, E-ISSN: 2222-6990 @ 2020 HRMARS

value of 1 when country $i$ is non-member of ACFTA and $j$ is a member in year t, zero otherwise. ${ }^{*} p<$ $10 \%$ level of significance. ${ }^{* *} p<5 \%$ level of significance. ${ }^{* * *} p<1 \%$ level of significance.

The coefficients of $A E C_{-} 1_{i j t}, A E C_{-} 2_{i j t}$ and $A E C_{-} 3_{i j t}(-1.285,-1.386,-1.338$ respectively) are reported as negative and statistically significant for machines and apparatus products. The negative coefficients of $A E C_{-} 1_{i j t} A E C_{-} 2_{i j t}$ reflects export diversion and export contraction effects of $A E C$ agreement on machines $\&$ apparatus category. Also, negative coefficient of $A E C_{-} 1_{i j t}$, alone with negative the coefficients of $A E C_{-} 3_{i j t}$, indicates the imports diversion and import contraction for this category of manufactured products. Thus, an overall trade diversion and trade contraction effects in terms of both exports and imports due to the AEC implementation are identified in this model for machines \& apparatus category.

\section{Trade Creation \& Diversion Effects}

Table 2 shows the summary of trade creation and diversion effects of AEC. When AEC_1 $1_{\mathrm{ijt}}$ effect is estimated for different commodities, there are substantial trade diversion effects for the exports of the machines \& apparatus, miscellaneous manufactured articles, manufactures of plaiting material \& basketwork and tobacco \& manufactured tobacco substitutes. Besides, trade creation effects for fur-skins \& artificial fur manufactures and limestone materials for manufacture of lime or cement are also created by AEC.

As AEC_2 $2_{\mathrm{ijt}}$ is estimated for the different products, there are substantial trade diversion effects for the exports of machines \& apparatus, even if the trade diversion effects for fur-skins \& artificial fur manufactures, as well as the miscellaneous manufactured articles are small.

When AEC_ $3_{\mathrm{ijt}}$ is estimated for different groups of products, there are substantial trade creation effects for the exports of tobacco \& manufactured tobacco substitutes as well as the manufactures of plaiting material \& basketwork, though the trade creation effects for miscellaneous manufactured articles as well as the limestone materials for manufacture of lime or cement are small. Meanwhile, there are significant trade diversion effects in the exports of machines \& apparatus.

Above all, the bilateral exports of fur-skins \& artificial fur manufacture, manufactures of plaiting material \& basketwork, miscellaneous manufactured articles, and machines \& apparatus presented its net trade diversion effect at the values of $-1.30,-0.23,-0.91$ and -4.01 , respectively, which equals to the percentage decrease of $72.77 \%, 20.35 \%, 59.91 \%$, and $98.18 \%$ in the bilateral trade volumes attributable to the signing of the AEC agreements in 2007.

In contrast, the net trade creation effect of AEC for tobacco \& manufactured tobacco substitutes, and limestone materials for manufacture of lime or cement are reported as 0.47 and 0.24 , which are on par with the percentage increase of $59.36 \%$ and $27.25 \%$ in the bilateral manufacturing trade volumes. Taken as a whole, there are substantial trade creation effects for the exports of tobacco \& manufactured tobacco substitutes, even if the trade creation effects in favor of the limestone materials for manufacture of lime or cement, is small. On the other hand, there are substantial trade diversion effects for the exports of the fur-skins \& artificial fur manufactures, manufactures of plaiting material \& basketwork, miscellaneous manufactured articles, as well as the machines \& apparatus. 
INTERNATIONAL JOURNAL OF ACADEMIC RESEARCH IN BUSINESS AND SOCIAL SCIENCES Vol. 10, No. 2, Feb, 2020, E-ISSN: 2222-6990 @ 2020 HRMARS

Table 2: Summary of trade creation effects for AEC

$\begin{array}{lllll}A E C_{-} 1_{i j t}\left(\theta_{1}\right) & A E C \_2_{i j t} & A E C_{-} 3_{i j t} & \text { Net effect } & \begin{array}{l}\text { Net Trade } \\ \text { Creation }\end{array} \\ \left(\theta_{2}\right) & \left(\theta_{3}\right) & & \text { Creation }\end{array}$

(Diversion) \%

\begin{tabular}{llllll}
\hline $\begin{array}{l}\text { Tobacco \& } \\
\text { manufactured } \\
\text { tobacco substitutes }\end{array}$ & -1.033 & & 1.499 & 0.47 & $59.36 \%$ \\
\hline $\begin{array}{l}\text { Fur-skins \& artificial } \\
\text { fur, manufactures } \\
\text { thereof }\end{array}$ & -0.883 & -0.418 & & -1.30 & $-72.77 \%$ \\
\hline $\begin{array}{l}\text { Manufactures of } \\
\text { plaiting material, } \\
\text { basketwork, etc. }\end{array}$ & -1.107 & -0.3625 & 1.242 & -0.23 & $-20.35 \%$ \\
\hline $\begin{array}{l}\text { Miscellaneous } \\
\text { manufactured } \\
\text { articles }\end{array}$ & -1.266 & -0.532 & 0.884 & -0.91 & $-59.91 \%$ \\
\hline $\begin{array}{l}\text { Limestone materials } \\
\text { for manufacture of }\end{array}$ & -0.321 & & & \\
lime or cement & \& & & 0.562 & 0.24 & $27.25 \%$ \\
\hline $\begin{array}{l}\text { Machines } \\
\text { apparatus }\end{array}$ & & & & \\
\hline
\end{tabular}

Note: Only significant effects are included in calculation of net effect.

\section{Summary and Conclusion}

This study aims to examine the impact of the signing of ASEAN Economic Community (AEC) blueprint on the bilateral aggregate and manufacturing trade between the member countries of ASEAN and its trading partners.

In the present study, the gravity model is employed in panel estimation from the period of 1995 to 2014 between the ASEAN-10 members and its 39 trading partners. Generally, the study found that the economic sizes, populations, relative endowments, distance and common languages can be included as the major determinants of the bilateral trade for ASEAN member countries.

The results for tobacco and manufactured tobacco substitutes, fur-skins \& artificial fur, and manufactures of plaiting material \& basketwork productsrevealed that the AEC has generated the trade diversion as well as reduction of intra-bloc exports of tobacco \& manufactured tobacco substitutes. An overall trade diversion effects attributable to the AEC implementation in terms of exports and imports for limestone materials for manufacture of lime or cement and machines \& apparatus are identified.

The significantly positive results for aggregate data confirm that reduction and elimination of the tariff barriers in AEC stimulate the total aggregate trade between intra-bloc member countries, intrabloc countries as well as extra-bloc countries. As the overall effects of AEC are estimated for different group of commodities, there are substantial trade creation effects for the exports of tobacco \& manufactured tobacco substitutes, though the trade creation effects for limestone materials for manufacture of lime or cement, is small. On the other hand, there are substantial trade diversion 
INTERNATIONAL JOURNAL OF ACADEMIC RESEARCH IN BUSINESS AND SOCIAL SCIENCES Vol. 10, No. 2, Feb, 2020, E-ISSN: 2222-6990 @ 2020 HRMARS

effects for the exports in the fur-skins \& artificial fur manufactures, manufactures of plaiting material \& basketwork, miscellaneous manufactured articles, as well as the machines \& apparatus.

\section{References}

Kumar, N. (2002a): Towards an Asian Economic Community- Vision of Closer Economic Cooperation in Asia: An Overview, Research and Information System for Non-Aligned and other Developing countries. (RIS) Discussion Paper No. 32.

Austria, M. S. (2004). Strategies towards an ASEAN Economic Community. CBERD Working Paper Series No. 2.

Baier, S. L., \& Bergstrand, J. H. (2007). Do Free Trade Agreements Actually Increase Members' International Trade? Journal of International Economics, 71(1), 72 - 95.

Cuyvers, L., Lombaerde, P. D., \& Verherstraeten, S. (2005). From AFTA towards an ASEAN economic community... and beyond. Centre for ASEAN Studies (CAS) Discussion paper No. 46.

Soesastro, H. (2005). Accelerating ASEAN Economic Integration: Moving Beyond AFTA. CSIS Working Paper Series No.091.

Soesastro, H. (2005). On ASEAN Economic Community. The Indonesian Ekonomists Association, Indonesian Economic Journal, 1.

Plummer, M. G. (2006). The ASEAN Economic Community and the European Experience. ADB Working Paper Series on Regional Economic Integration No.1.

Baier, S. L., \& Bergstrand, J. H. (2007). Do Free Trade Agreements Actually Increase Members' International Trade?. Journal of International Economics, 71: 72-95.

Ismail, N. W., Smith, P., \& Kugler, M. (2007). Regional Economic Integration and Intra Regional Trade: The Evidence from the Association of Southeast Asian Nations (ASEAN) Free Trade Area. In Proceedings of 2007 Singapore Economic Review Conference.

Garcia, E. C., Pabsdorf, M. N., \& Herrera, E. G. (2013). The Gravity Model Analysis: An Application on MERCOSUR Trade Flows. Journal of Economic Policy Reform, 16(4):336-348.

Oh, J., \& Sardar, R. R. (2013). Gravity Matters: International Trade of Bangladesh. Review of Urban \& Regional Development Studies, 25(1): 34-46.

Centre d'Etudes Prospectives et d'Informations Internationales. (2014). Geographical variables. Retrieved from http://www.cepii.fr/CEPII/en/bdd_modele/presentation.asp?id=6.

Centre d'Etudes Prospectives et d'Informations Internationales. (2014). Languages. Retrieved from http://www.cepii.fr/CEPII/en/bdd_modele/presentation.asp?id=19.

International Monetary Fund, Direction of International Trade Statistics Yearbook. (2014). Retrieved from http://data.imf.org/?sk=9D6028D4-F14A-464C-A2F2-59B2CD424B85.

International Monetary Fund, International Financial Statistics Yearbook (2014). Retrieved from http://data.imf.org/?sk=5DABAFF2-C5AD-4D27-A175-1253419C02D1.

The United Nation Commodity Trade Statistics Database. (2015). Retrieved from http://comtrade.un.org/db

The United Nation Conference on Trade and Development database. (2016). Retrieved from http://unctadstat.unctad.org/EN/Index.html

The World Bank, World Development Indicators (2014). GDP (current US\$). Retrieved from http://data.worldbank.org/indicator/NY.GDP.MKTP.CD 
INTERNATIONAL JOURNAL OF ACADEMIC RESEARCH IN BUSINESS AND SOCIAL SCIENCES

Vol. 10, No. 2, Feb, 2020, E-ISSN: 2222-6990 ¿ 2020 HRMARS

The World Bank, World Development Indicators. (2014). Population, total. Retrieved from http://data.worldbank.org/indicator/SP.POP.TOTL

Yang, S., \& Martinez-Zarzoso, I. (2014). A Panel Data Analysis of Trade Creation and Trade Diversion Effects: The case of ASEAN-China Free Trade Area. China Economic Review, 29: 138-151.

Panda, R., \& Sethi, M. (2015). India and Bilateral Trade: A Gravity Model Approach. International Journal of Business Insights \& Transformation, 8(2): 30-37.

Sultan, M. \& Munir, K. (2015). Export, Import and Total Trade Potential of Pakistan: A Gravity Model Approach. Munich Personal RePEc Archive MPRA Paper No. 66621.

Tumwebaze, H. K., \& Nahamya, W. K. (2015). Determinants of Uganda's Export Performance: A Gravity Model Analysis. International Journal of Economics and Business Studies, 5(1-2): 318.

Eita, J. H. (2016). Estimating Export Potential for a Small Open Economy Using a Gravity Model Approach: Evidence from Namibia. The Journal of Developing Areas, 50(4): 273-288.

Rasoulinezhad, E., \& Kang, G. S. (2016). A Panel Data Analysis of South Korea's Trade with OPEC Member Countries: The Gravity Model Approach. Iranian Economic Review, 20(2): 203-224. 